\title{
REVIEW
}

\section{Diseases of Echinodermata. I. Agents microorganisms and protistans*}

\author{
Michel Jangoux \\ Laboratoire de Biologie marine (CP 160), Université Libre de Bruxelles, Ave F. D. Roosevelt 50, B-1050 Bruxelles, Belgium
}

\begin{abstract}
Diseases caused by microorganisms have been observed mostly in regular echinoids. The causative agents are either bacteria or fungi. Sporozoans are the most common protistan agents. They basically infest the hemal and coelomic fluids of holothuroids and spatangoid echinoids. A single species of ciliate is known to parasitize echinoderms; it causes the castration of asteroids testes. Protophytans causing lethal lesions in the body wall of asteroids and ophiuroids have been reported casually. Widespread mass mortalities of echinoids, presumably due to bacteria or protistans, have been recorded repeatedly in the last $10 \mathrm{yr}$
\end{abstract}

\section{INTRODUCTION}

Representatives of most marine phyla are known to live in close association with echinoderms (for reviews see Ludwig \& Hamann 1889-1907, Hyman 1955, Barel \& Kramers 1977, Jangoux 1984). Authors who reported such associations focussed in most cases on associated species - their taxonomy and morphology - and discussed very briefly, if at all, the true nature of the hostassociate relation. Consequentiy, many associated species were termed parasitic or semi-parasitic when they were in reality commensal or simply phoretic. So far, most reports on biotic diseases of echinoderms refer to animal agents. Disease agents are not necessarily parasites in the classical sense, i.e. associated organisms which are provided with host substances that are essential for their nutritional requirement' (Baer 1951, p. 6). Numerous echinoderm associates

\footnotetext{
- Editorial Note. This is the first of a total of 4 reviews by M. Jangoux summarizing our present knowledge on the diseases of echinoderms. Originally, it was planned to publish these accounts in Volume III of 'Diseases of Marine Animals' (Editor O. Kinne; Publisher: Biologische Anstalt Helgoland, Hamburg). However, 2 major contributors to the volume failed to submit their manuscripts. Hence, Volume III must now be reorganized; it will appear at a later date
}

may exert detrimental effects although they do not feed on the host's tissues or fluids. In this context Kinne's (1980, p. 19) definition of parasites is much more satisfactory as it does not imply an obligatory trophic relation but only a detrimental effect. According to Kinne 'parasitism involves an intimate coexistence of heterospecific organisms which is characterized by the fact that one of the organisms involved (the parasite) obtain benefits (e.g. energy, matter) at the expense of the other (the host); parasitism often tends to result in demonstrable negative effects in the host. The (metabolic) dependence of the parasite may be facultative (facultative parasite) or obligate (obligate parasite)'. I have adopted that definition and used it in a very broad sense, considering disease agents (parasites sensu lato) to represent any kind of a harmful associate which affects, if even slightly, the host's tissues or internal fluids (i.e. coelomic and hemal fluids).

The present paper is the first of a series of 4 that will review the diseases of Echinodermata. I shall consider the different groups of disease agents - ranging from Bacteria to Chordata - which are known to affect echinoderms (Parts I to III), and then consider the location and effects of these agents, as well as the reaction and sensitivity of echinoderms to pathogens (Part IV). 


\section{DISEASES CAUSED BY MICROORGANISMS}

\section{Agents: Bacteria}

Non-pathological bacteria occur naturally in echinoderms, for instance gut-associated bacteria of some echinoids (e.g. Unkles 1977 and Guerinot \& Patriquin 1981 who studied regular echinoids; De Ridder et al. 1985 who reported on spatangoid echinoids), or subcuticular bacteria observed in most echinoderms (e.g. Holland \& Nealson 1978). However, healthy echinoids never harbor bacteria in their coelomic fluid which is normally sterile (Bang \& Lemma 1962, Wardlaw \& Unkles 1978, Kaneshiro \& Karp 1980). According to Bang \& Lemma, bacteria-infected coelomic fluid occurs in Asterias forbesi when the asteroid undergoes autotomy or is traumatized dermally. They reported also that such infections generally prevail when $A$. forbesi is collected from stagnant water, and disappear progressively after it has been returned to running seawater. Bang \& Lemma noted moreover that coelomic-fluid infection is accompanied by weight loss (presumably due to loss of coelomic fluid) correlated with the intensity of the infection.

Experimental infection of coelomic fluid of healthy asteroids or echinoids showed that bacterial (as well as viral, i.e. exotic virus) suspensions are cleared rather quickly from the body-cavity of echinoderms (Bang \& Lemma 1962, Coffaro 1978, Wardlaw \& Unkles 1978, Kaneshiro \& Karp 1980, Yui \& Bayne 1983). The elimination of bacteria appears to be chiefly the consequence of the activity of phagocytic coelomocytes (Johnson 1969, Johnson et al. 1970, Johnson \& Chap- man 1971, Kaneshiro \& Karp 1980). Antibacterial activities of coelomocytes are not restricted to phagocytosis: some echinoid coelomocytes release mucins which immobilize microorganisms entering the coelom (i.e. vibratile cells: Johnson 1969) or produce bactericidal substances (i.e. red spherule cells: Johnson 1969, Johnson \& Chapman 1971, Wardlaw \& Unkles 1978, Messer \& Wardlaw 1980, Service \& Wardlaw 1985). The bactericidal substances produced by the red spherule cells are naphthoquinone pigments belonging to the spinochrome (echinochrome) group (Service \& Wardlaw 1984).

Individuals of several species of littoral regular echinoids suffer from a spectacular disease - bald-seaurchin disease (Table 1) - causing conspicuous lesions on the body surface (Fig. 1). Generally this disease develops as follows (Johnson 1971, Maes and Jangoux 1984, Maes et al. 1986) : (1) the epidermis surrounding some spine bases turns green; (2) spines and other appendages are lost and the green epidermis and its underlying dermal tissue become necrotic; (3) epidermis and superficial dermal tissue are lost and circularto-elongate denuded test areas are formed; (4) the upper layer of the skeleton is partially destroyed. When lesions are of limited size, the diseased individuals may recover: the affected skeleton is simply eliminated (Fig. 2), and the body-wall tissues and outer appendages are regenerated. According to Maes \& Jangoux (1984) death occurs either with lesions extending over a large area (more than $30 \%$ of the total body surface) or with deep lesions involving test perforations (see also Gilles \& Pearse 1986). Affected echinoids develop a conspicuous inflammatory-like

Table 1. Records of bald-sea-urchin disease (after Maes \& Jangoux 1984; expanded)

\begin{tabular}{|c|c|c|}
\hline Species & Geographical area & Sources \\
\hline Allocentrotus fragilis & N.E. Pacific (California) ('red spot disease') & Boolootian et al. (1959), Giese (1961) \\
\hline Arbacia lixula & Western Mediterranean Sea (French coast) & $\begin{array}{l}\text { Höbaus et al. (1981), Maes \& Jangoux } \\
\text { (1984) }\end{array}$ \\
\hline Cidaris cidaris & Western Mediterranean Sea (French coast) & Fenaux, in Maes \& Jangoux (1984) \\
\hline Echinus esculentus & N.E. Atlantic Ocean (Brittany coast) & Nichols (1979), Maes \& Jangoux (1984) \\
\hline Paracentrotus lividus & $\begin{array}{l}\text { Western Mediterranean Sea (Alicante, Spain; } \\
\text { French coast; S. Italy and Sicily; Rijeka, } \\
\text { Yugoslavia), N.E. Atlantic Ocean (Brittany) }\end{array}$ & $\begin{array}{l}\text { Höbaus et al. (1981), Boudouresque et } \\
\text { al. (1980, 1981), Azzolina (1983), Maes } \\
\text { \& Jangoux (1984), Maes et al. (1986) }\end{array}$ \\
\hline Psammechinus miliaris & English Channel (Normandy, France) & $\begin{array}{l}\text { Maes \& Jangoux (1984), Maes et al. } \\
\text { (1986) }\end{array}$ \\
\hline Sphaerechinus granularis & $\begin{array}{l}\text { Western Mediterranean Sea (French coast), } \\
\text { N.E. Atlantic Ocean (Brittany) }\end{array}$ & $\begin{array}{l}\text { Höbaus et aI. (1981), Maes \& Jangoux } \\
\text { (1984) }\end{array}$ \\
\hline Strongylocentrotus droebachiensis & N.W. Atlantic Ocean (Nova Scotia) & Scheibling \& Stephenson (1984) \\
\hline Strongylocentrotus franciscanus & N.E. Pacific Ocean (California) & $\begin{array}{l}\text { Johnson (1971), Pearse et al. (1977), } \\
\text { Pearse \& Hines (1979) }\end{array}$ \\
\hline Strongylocentrotus purpuratus & N.E. Pacific Ocean (California) & Johnson (1971), Gilles \& Pearse (1986) \\
\hline
\end{tabular}



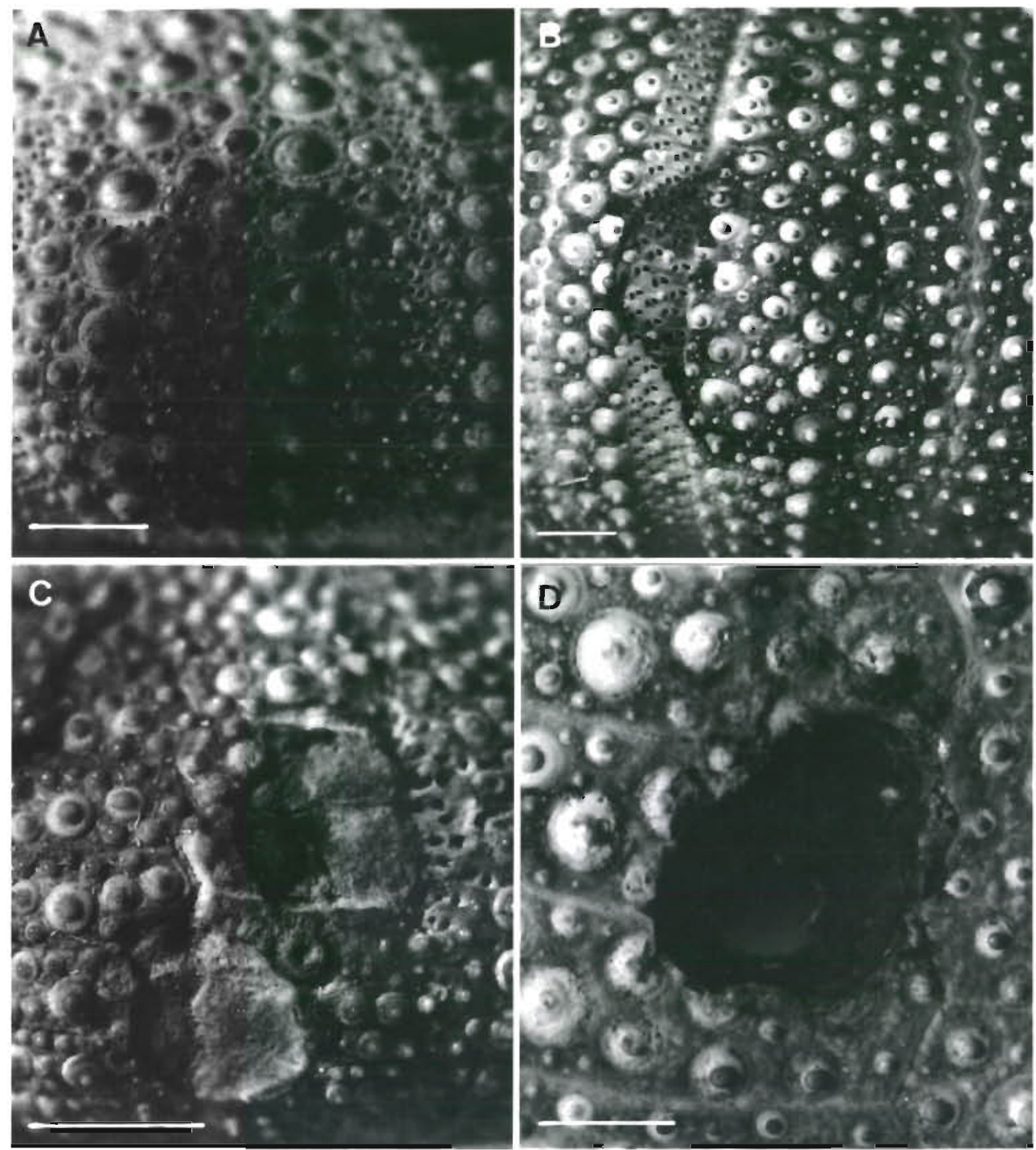

Fig. 1. Traces produced by bald-sea-urchin disease on the echinoid test skeleton (bar $=5 \mathrm{~mm}$ ). (A) Paracentrotus lividus. Greenish-colored area (early infection). (B) Echinus esculentus. Greenish-colored area (late infection). (C) Psammechinus miliaris. Depressed test area. (D) Echinus esculentus. Perforated test area. (After Maes \& Jangoux 1984)

Fig. 2. Effects of bald-sea urchin disease on the echinoid skeleton. (A) Superficial infection; (B \& C) lethal infections; (D) elimination of affected skeletal layer (usually followed by echinoid recovery); (E) perforation of skeleton involving death of the echinoid. (After Maes \& Jangoux 1984)
A

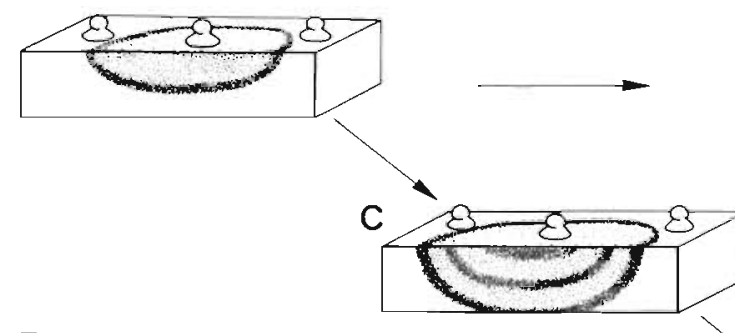

B

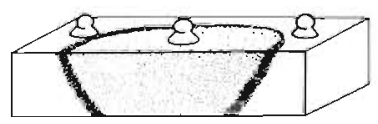

$\mathrm{D}$

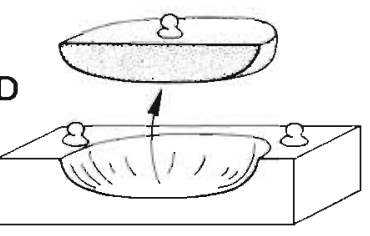


reaction around the area concerned. There is a massive migration of coelomocytes, i.e. phagocytic cells and red spherule cells, around and within the affected area (Johnson 1971, Maes \& Jangoux 1984, Gilles \& Pearse 1986, Maes et al. 1986).

Bald-sea-urchin disease is communicable. Pieces of necrotic tissues initiate the disease when painted on experimentally produced injuries of the outer body surface of healthy echinoids (Maes \& Jangoux 1984, Gilles \& Pearse 1986). Maes \& Jangoux also showed that the disease- is not species-specific: it is easy to experimentally infect regular echinoids of several different species.

The causative agent of bald-sea-urchin disease is of bacterial nature (Maes \& Jangoux 1985, Gilles \& Pearse 1986). Gilles \& Pearse isolated 14 different bacterial strains from lesions of diseased Strongylocentrotus purpuratus. They demonstrated that only the isolates of Vibrio anguillarum and Aeromonas salmonicida - 2 well-known pathogenic marine bacteria - were able to initiate lesion formation in the laboratory. Both Maes \& Jangoux (1984) and Gilles \& Pearse (1986) concluded from experimental infectivity tests that a stress such as physical injury is necessary for the formation of characteristic lesions. As suggested by Maes et al. (1986), lesions may possibly be caused by bacteria that are resistant to the antibacterial substances naturally produced by the echinoids, namely the naphthoquinone pigments conveyed by the red spherule cells.

Several authors reported mass mortalities of echinoids, presumably due to bald-sea-urchin disease. Mass mortalities affected 60 to $95 \%$ of Strongylocentrotus franciscanus and 10 to $75 \%$ of Paracentrotus lividus (Pearse et al. 1977, Boudouresque et al. 1980, 1981, respectively). Azzolina (1983) noted that mortality of $P$. Lividus is higher in shallow waters, and that diseased individuals are more numerous during summer. However, as noted by Gilles \& Pearse (1986), there are also reports of lesions on occasional individuals in populations of otherwise healthy echinoids (e.g. Pearse et al. 1977, Maes \& Jangoux 1984).

Bacteria do not seem to be the causative agents of the disease causing mass mortalities of Strongylocentrotus droebachiensis along the Atlantic coast of Canada (e.g. Miller \& Colodey 1983). Although characteristic bacterial lesions do sometimes occur on these echinoids (Scheibling \& Stephenson 1984), the bacteria could have been a secondary factor associated with the mass mortality as suggested by Gilles \& Pearse (1986). In such a case it may be supposed that bacteria developed on echinoids previously infested by a not yet identified pathogen that caused lysis of tube feet and loss of spines (see Jones et al. 1985b) (see p. 159).
Scattered information on other types of bacterial infection can be found in the literature. Olmsted (1917) noticed several small dark brown-green spherical masses of up to $1.5 \mathrm{~mm}$ in diameter in the body cavity of almost all individuals of the holothuroid Synaptula hydriformis examined. These masses consisted of 'bacterial parasites' belonging to the genus Mycrocystus. Mortensen (1935) observed granular epidermal swellings on the echinoid Calveriosoma gracile. According to him these swellings were very probably of bacterial nature. Delavault \& Leclerc (1969) briefly reported a bacterial disease affecting Asterina gibbosa under aquarium conditions. Diseased asteroids show patches of epidermal necrosis which progressively unite and finally cause death.

\section{Agents: Fungi}

Mortensen (1909, 1928, 1936) and Koehler (1911, 1912) reported a very peculiar disease that affects several species of Antarctic cidaroid echinoids (genera Rhynchocidaris and Ctenocidaris). The disease is caused by an agent (Echinophyces mirabilis) which according to Mortensen (1909) is likely a fungus. The pathogen lives in the echinoid's primary spines which are much more slender and fragile than those of healthy echinoids (Fig. 3). As infected individuals are typically smaller than healthy ones, Mortensen concluded that the parasite interferes with growth and dwarfs the specimens. He pointed out that the presumed fungus had no castrating effect but caused a very unusual abnormality on the echinoid test: in infected individuals the genital pores, presumably together with the genital or apical plates, are not in their usual place in the apical system but displaced to the edge of the peristome; consequently, new(?) genital ducts are formed leading to the peristomeal pores. Mortensen made no proposal as to how the parasite could 'move' the genital pores. He noted, however, that a few specimens had their genital pores in the middle of the interambulacra. All this suggests that the fungus could perhaps modify normal echinoid test growth (new skeletal plates of the test always differentiate just at the outer edge of the apical plates and grow when migrating down; Märkel 1981). In other words, the abnormalities observed could mean that the apical plates of infected echinoids lose their specificity in behaving like any other test plates and that they consequently migrate downwards. The position of genital pores - in the middle of the interambulacra or near the peristome - would consequently differ according to whether the echinoid was infected immediately following metamorphosis or later during juvenile growth.

No other fungal disease has been reported from 
Fig. 3. Infection of primary spines of the cidaroid echinoid Rhynchocidans triplopora by the fungus Echinophyces mirabilis. (A) \& (B) Cross-sections through (A) healthy and (B) infected primary spines; (C \& D) outer views of (C) healthy and (D) infected primary spines; ( $E \&$ F) aspect and location of parasite within a primary spine. (After Mortensen 1909)


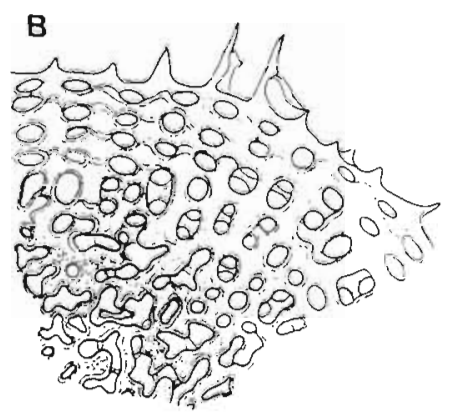

D

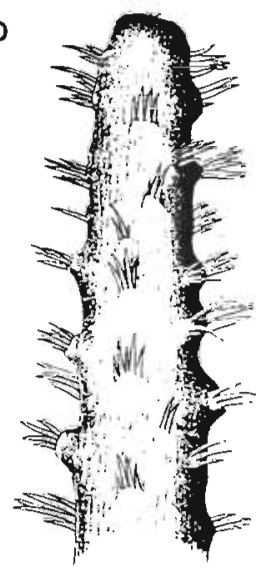

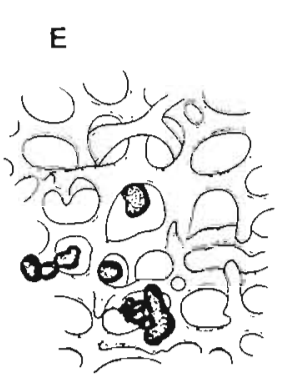

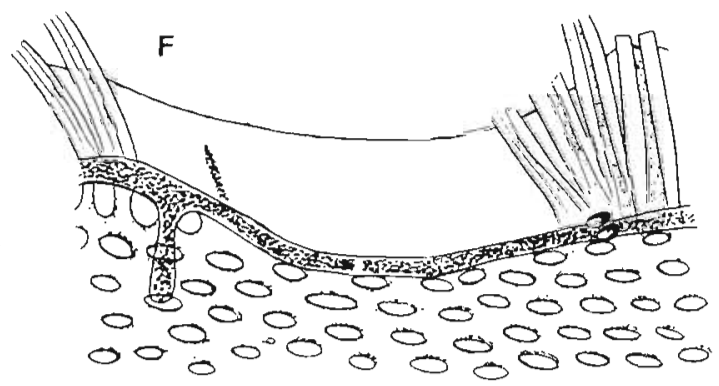

echinoderms, except that Mortensen (1940) briefly described a fungus-like organism within the primary spines of Diadema antillarum. It causes hypertrophy of the calcareous mass of spines and an irregular growth of their edge. Johnson \& Chapman (1970b) briefly reported the occurrence of fungi on and within the regenerating spines of some individuals of Strongylocentrotus franciscanus.

\section{Agents: Cyanophyta}

In a single specimen of the echinoid Echinus acutus, collected off Bergen (Norway), Mortensen \& Rosevinge (1934) found the body wall to be locally deprived of appendages and epidermis. Patches of denuded test areas showed a typical blue-green color. According to the authors the disease was caused by the blue-green alga Dactylococcopsis echini. Actually the alga was identified on smears made from necrotic tissues but was not recognized in histological sections; the pathogenic nature of $D$, echini remains to be proven. The disease possibly destroys the calcified tissue and produces an intense reaction of amoeboid cells which invade massively the necrotic area. This symptomatology is similar to that of bald-sea-urchin disease.

\section{DISEASES CAUSED BY PROTOZOANS}

\section{Agents: Flagellata and Sarcodina}

As quoted by Barel \& Kramers (1977), the flagellate Oikomonas echinorum, noted by Cuénot (1912) in the general body cavity of most European echinoids, is a 
Table 2. Parasitic sporozoans (Apicomplexa) from echinoderms (compiled from the sources indicated)

\begin{tabular}{|c|c|c|c|c|}
\hline Sporozoa ${ }^{1}$ & Hosts $^{2}$ & Location in host & Geographical area & Source \\
\hline \multicolumn{5}{|l|}{ GREGARINIA } \\
\hline $\begin{array}{l}\text { Cystobia } \\
\text { grassei }\end{array}$ & $\begin{array}{l}\text { Holothuria tubulosa, } \\
\text { Holothuria stellati (H) }\end{array}$ & $\begin{array}{l}\text { Gut-associated hemal } \\
\text { system; coelomic cavity }\end{array}$ & $\begin{array}{l}\text { Mediterranean Sea } \\
\text { (Banyuls) }\end{array}$ & Changeux (1961) \\
\hline $\begin{array}{l}\text { Cystobia } \\
\text { holothuriae }\end{array}$ & $\begin{array}{l}\text { Holothuria tubulosa, } \\
\text { Holothuria stellati }(\mathrm{H})\end{array}$ & $\begin{array}{l}\text { Gut-associated hemal } \\
\text { system; coelomic cavity }\end{array}$ & $\begin{array}{l}\text { Mediterranean Sea } \\
\text { (Banyuls, Naples, Nice) }\end{array}$ & $\begin{array}{l}\text { Schneider (1858), Mingazzini } \\
\text { (1891), Minchin (1893), } \\
\text { Changeux (1961) }\end{array}$ \\
\hline $\begin{array}{l}\text { Cystobia } \\
\text { irregularis }\end{array}$ & Holothuria forskali $(\mathrm{H})$ & Hemal system & $\begin{array}{l}\text { English Channel } \\
\text { (Plymouth) }\end{array}$ & $\begin{array}{l}\text { Minchin }(1893), \text { Woodcock } \\
(1902,1904,1906)\end{array}$ \\
\hline $\begin{array}{l}\text { Cystobia } \\
\text { schneideri }\end{array}$ & $\begin{array}{l}\text { Holothuria tubulosa, } \\
\text { Holothuria poli, } \\
\text { Holothuria stellati(H) }\end{array}$ & $\begin{array}{l}\text { Gut-associated hemal } \\
\text { system; coelomic cavity }\end{array}$ & Mediterranean Sea & $\begin{array}{l}\text { Mingazzini (1891), Changeux } \\
\text { (1961) }\end{array}$ \\
\hline $\begin{array}{l}\text { Cystobia } \\
\text { stichopi }\end{array}$ & Parastichopus tremulus $(\mathrm{H})$ & $\begin{array}{l}\text { Radial hemal system } \\
\text { (dorsal radius only) }\end{array}$ & North Sea (Oslo Fjord) & $\begin{array}{l}\text { Lützen (1968), Jespersen \& } \\
\text { Lützen (1971) }\end{array}$ \\
\hline $\begin{array}{l}\text { Diplodina } \\
\text { gonadipertha }\end{array}$ & Cucumaria frondosa $(\mathrm{H})$ & On and in gonads & Barents Sea (Kola Bay) & Djakonov (1923) \\
\hline $\begin{array}{l}\text { Goniospora } \\
\text { merciert }\end{array}$ & Labidoplax digitata $(\mathrm{H})$ & $\begin{array}{l}\text { Gut associated hemal } \\
\text { system; coelomic cavity }\end{array}$ & $\begin{array}{l}\text { N.E. Atlantic } \\
\text { (Arcachon Bay) }\end{array}$ & $\begin{array}{l}\text { Cuénot (1912), Barel \& } \\
\text { Kramers (1977) }\end{array}$ \\
\hline $\begin{array}{l}\text { Lithocystis } \\
\text { brachycercus }\end{array}$ & Chirodota laevis $(\mathrm{H})$ & $\begin{array}{l}\text { Gut-associated hemal } \\
\text { system; coelomic cavity }\end{array}$ & $\begin{array}{l}\text { N.W. Atlantic (St. An- } \\
\text { drews, New Brunswick) }\end{array}$ & Pixell-Goodrich (1925) \\
\hline $\begin{array}{l}\text { Lithocystis } \\
\text { cucumariae }\end{array}$ & Pawsonia saxicola $(\mathrm{H})$ & Respiratory trees & $\begin{array}{l}\text { English Channel } \\
\text { (Plymouth) }\end{array}$ & Pixell-Goodrich (1929) \\
\hline $\begin{array}{l}\text { Lithocystis } \\
\text { foliacea }\end{array}$ & $\begin{array}{l}\text { Echinocardium } \\
\text { cordatum }(\mathrm{E})\end{array}$ & Coelomic cavity & $\begin{array}{l}\text { Mediterranean Sea (Nap- } \\
\text { les); English Channel } \\
\text { (Plymouth, Wimereux) }\end{array}$ & $\begin{array}{l}\text { Pixell-Goodrich (1915), } \\
\text { Coulon \& Jangoux (1987) }\end{array}$ \\
\hline $\begin{array}{l}\text { Lithocystis } \\
\text { latifronsi }\end{array}$ & Brisaster latifrons $(E)$ & Coelomic cavity & $\begin{array}{l}\text { N.E. Pacific (off Oregon } \\
\text { coast) }\end{array}$ & Brownell \& McCauley (1971) \\
\hline $\begin{array}{l}\text { Lithocystis } \\
\text { microspora }\end{array}$ & Spatangus purpuratus (E) & Coelomic cavity & English Channel & Pixell-Goodrich (1915) \\
\hline $\begin{array}{l}\text { Lithocystis } \\
\text { minchini }\end{array}$ & Pawsonia saxicola $(E)$ & Body wall (coelomic side) & $\begin{array}{l}\text { English Channel } \\
\text { (Plymouth) }\end{array}$ & $\begin{array}{l}\text { Woodcock (1906), Pixell- } \\
\text { Goodrich (1929) }\end{array}$ \\
\hline $\begin{array}{l}\text { Lithocystis } \\
\text { oregonensis }\end{array}$ & Brisaster latifrons $(\mathrm{E})$ & Coelomic cavity & $\begin{array}{l}\text { N.E. Pacific (off Oregon } \\
\text { coast) }\end{array}$ & Brownell \& McCauley (1971) \\
\hline $\begin{array}{l}\text { Lithocystis } \\
\text { schneideri }\end{array}$ & $\begin{array}{l}\text { Echinocardium } \\
\text { cordatum }(\mathrm{E})\end{array}$ & Coelomic cavity & $\begin{array}{l}\text { N.E. Atlantic (Arcachon); } \\
\text { Mediterranean Sea (Nap- } \\
\text { les)i English Channel } \\
\text { (Cabourg, Dunkerque, } \\
\text { Plymouth, Wimereux) }\end{array}$ & $\begin{array}{l}\text { Giard (1876), Cuénot (1891, } \\
\text { 1892, 1912), Léger (1896, } \\
\text { 1897), Pixell-Goodrich (1915), } \\
\text { De Ridder \& Jangoux (1984), } \\
\text { Coulon \& Jangoux (1987) }\end{array}$ \\
\hline $\begin{array}{l}\text { Urospora } \\
\text { chirodotae }\end{array}$ & Chirodota laevis $(\mathrm{H})$ & $\begin{array}{l}\text { Gut-associated hemal } \\
\text { system. }\end{array}$ & $\begin{array}{l}\text { Barents Sea (Murmansk)i } \\
\text { N.W. Atlantic (St. An- } \\
\text { drews, New Brunswick) }\end{array}$ & $\begin{array}{l}\text { Dogiel (1906), Pixel-Goodrich } \\
\text { (1925), Theodorides \& Laird } \\
\text { (1970) }\end{array}$ \\
\hline $\begin{array}{l}\text { Urospora } \\
\text { echinocardii }\end{array}$ & $\begin{array}{l}\text { Echinocardium cordatum, } \\
\text { Spatangus purpureus (E) }\end{array}$ & Coelomic cavity & $\begin{array}{l}\text { English Channel } \\
\text { (Plymouth) }\end{array}$ & Pixell-Goodrich (1915) \\
\hline $\begin{array}{l}\text { Urospora } \\
\text { intestinalis }\end{array}$ & Cucumariajaponia $(\mathrm{H})$ & $\begin{array}{l}\text { Gut-associated hemal } \\
\text { system }\end{array}$ & $\begin{array}{l}\text { N.W. Pacific (Peter the } \\
\text { Great Bay) }\end{array}$ & $\begin{array}{l}\text { Bogalepova (1953, quoted by } \\
\text { Changeux 1961) }\end{array}$ \\
\hline $\begin{array}{l}\text { Urospora } \\
\text { neapolitana }\end{array}$ & $\begin{array}{l}\text { Echinocardium } \\
\text { cordatum }(\mathrm{E})\end{array}$ & Coelomic cavity & $\begin{array}{l}\text { Mediterranean Sea } \\
\text { (Naples); English } \\
\text { Channel (Wimereux) }\end{array}$ & $\begin{array}{l}\text { Pixell-Goodrich (1915), } \\
\text { Coulon \& Jangoux (1987) }\end{array}$ \\
\hline $\begin{array}{l}\text { Urospora } \\
\text { pulmonalis }\end{array}$ & Cucumaria japonica $(\mathrm{H})$ & Respiratory trees & $\begin{array}{l}\text { N.W. Pacific (Peter the } \\
\text { Great Bay) }\end{array}$ & $\begin{array}{l}\text { Bogolepova (1953; quoted by } \\
\text { Changeux 1961) }\end{array}$ \\
\hline $\begin{array}{l}\text { Urospora } \\
\text { synaptae }\end{array}$ & $\begin{array}{l}\text { Leptosynapta galliennei, } \\
\text { Leptosynapta inhaerens }(\mathrm{H})\end{array}$ & $\begin{array}{l}\text { Gut-associated hemal } \\
\text { system; coelomic cavity }\end{array}$ & $\begin{array}{l}\text { N.E. Atlantic (Arcachon, } \\
\text { Morgat, Roscoff) }\end{array}$ & $\begin{array}{l}\text { Cuênot }(1891,1892,1912) \\
\text { Barel \& Kramers }(1970)\end{array}$ \\
\hline $\begin{array}{l}\text { COCCIDIA } \\
\text { Lxoreis psy- } \\
\text { chropotae }\end{array}$ & $\begin{array}{l}\text { Psychropotes } \\
\text { longicauda }(\mathrm{H})\end{array}$ & $\begin{array}{l}\text { Mostly gut-associated } \\
\text { hemal system }\end{array}$ & $\begin{array}{l}\text { N.E. Atlantic (Bay of } \\
\text { Biscay: deep sea) }\end{array}$ & Massin et al. (1978) \\
\hline $\begin{array}{l}{ }^{1} \text { Specific names } \\
{ }^{3} \text { Generic positic }\end{array}$ & $\begin{array}{l}\text { according to Pixell-Goodrick } \\
\text { on unclear. }{ }^{4} \text { Possibly syno }\end{array}$ & $\begin{array}{l}915-1929) \text { and Levine (19 } \\
\text { m of Urospora synaptael }\end{array}$ & $\begin{array}{l}{ }^{2} \text { E: echinoid } \mathrm{H} \text { : holo } \\
\text { Barel \& Kramers } 1977 \text { ) }\end{array}$ & huroid. \\
\hline
\end{tabular}


particular type of coelomocyte known as vibratile cell'. According to Lecal (1980) the bodonid flagellate Cryptobia antedonae occurs in the coelomic fluid of Antedon bifida, but no information is given on the relation between crinoid and flagellate. Unidentified flagellates were noted also by Chesher (1969) in the body cavity of the spatangoid Meoma ventricosa.

An unidentified amoeboid protozoan infesting the ovaries of the echinoid Arbacia lixula near Naples (Italy) was recorded by Janssens (1903). The protozoan actively ingests ovocytes, with the parasitized echinoids remaining seemingly healthly. Amoebae (Paramoeba sp.) have been found consistently in tissues of echinoids Strongylocentrotus droebachiensis affected by a disease causing mass mortality in Nova Scotia (Jones et al. 1985b). It has not been determined, however, whether these amoebae are the causative agent or only secondary invaders.

\section{Agents: Sporozoa (Apicomplexa)}

Apicomplexa parasitize only holothuroids and spatangoid echinoids. So far they have never been observed in crinoids, asteroids or ophiuroids. About 23 species are known from echinoderms, among them 22 gregarines and 1 coccidian (Table 2). Undoubtedly there are many more species of Apicomplexa infesting echinoderms; numerous authors reported the occurrence, either in the hemal system or in the coelomic cavity, of cysts belonging to undescribed species (e.g. Hérouard 1902, Changeux 1961, Chesher 1968, 1969, Brownell \& McCauley 1971, Jesperson \& Lützen 1971. Massin 1984).

Echinoderms are infested mainly by 3 gregarine genera: Cystobia, Lithocystis and Urospora (Family Urosporidae, Order Eugregarinida; see Levine 1977).
Deposit-feeding echinoderms are very sensitive to gregarine infestations (Table 2). They may infest themselves simply by swallowing sediment that contains mature cysts. The cysts are broken down and sporozoites are liberated owing to the physico-chemical properties of the digestive fluid.

A more or less prolonged stay in the host's hemal system appears to be necessary for gregarine development in deposit-feeding holothuroids (Minchin 1893, Cuénot 1912, Pixell-Goodrich 1925, Changeux 1961). As shown by Changeux in Holothuria spp. simultaneously infested by 3 different species of Cystobia, trophozoites and subsequent cysts colonize particular hemal areas (see also Lützen 1968). Changeux (1961) claimed that the location may be considered a speciesspecific character. Most of the life cycle of Cystobia spp. occurs within the holothuroid hemal system. Growth of the Cystobia trophozoite progressively occludes the host's hemal lacuna. A peculiar hemal outgrowth is formed that looks like a bell-clapper protruding into the coelomic cavity. The clapper represents the so-called 'stalked gregarine' (Fig. 4). It is formed by an evagination of the underlying hemal lacuna whose distal end encloses an enlarged trophozoite or cyst. Mature cysts generally reach the coelomic cavity either by the stalk breaking off or by tearing off its distal end. Cysts in the coelomic cavities frequently are embedded in brown bodies (Briot 1906 , Arvy 1957, Changeux 1961).

Other parasitic gregarines from deposit-feeding holothuroids (Lithocystis spp. and Urospora spp.) do not produce 'hemal stalks'. Urospora chirodotae is known only from the gut-associated hemal system of Chirodota laevis, and seemingly does not occur in its coelomic cavity (Dogiel 1906, Pixell-Goodrich 1925). In contrast, U. synapta and L. brachycercus (Cuénot 1912, Pixell-Goodrich 1925, respectively) occur in the gut-
Fig. 4. Cystobia grassei, a stalked gregarine from the holothuroid Holothuria tubulosa. (A) Section of gut and associated hemal system showing location (arrow) of the cyst. i: intestine; $r$ : rete mirabile. (B) Stalked gametocyst. (After Changeux 1960)
A

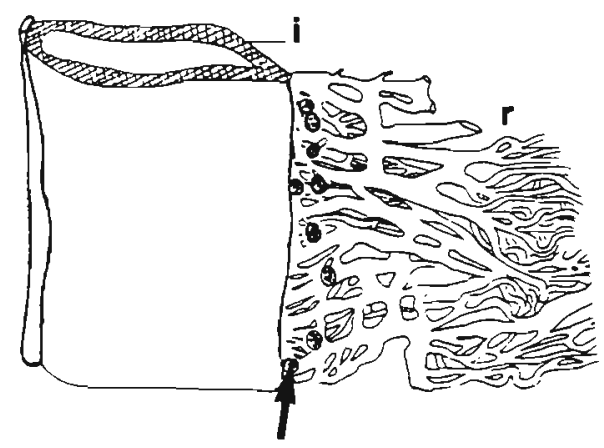

$2 \mathrm{~m} \mathrm{~m}$
B

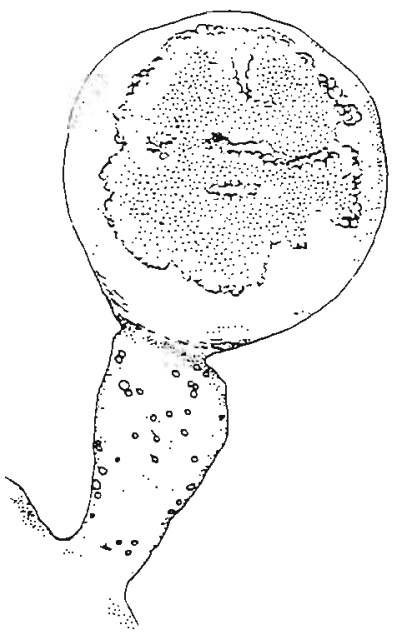

$200 \mu \mathrm{m}$ 
associated hemal system and in the coelomic cavity of their host, pre-mature cysts and even trophozoites being often present in the coelomic cavity.
In most gregarines from spatangoids, the whole life cycle occurs within the coelomic cavity (Fig. 5) Gametocysts are often embedded in brown bodies (De
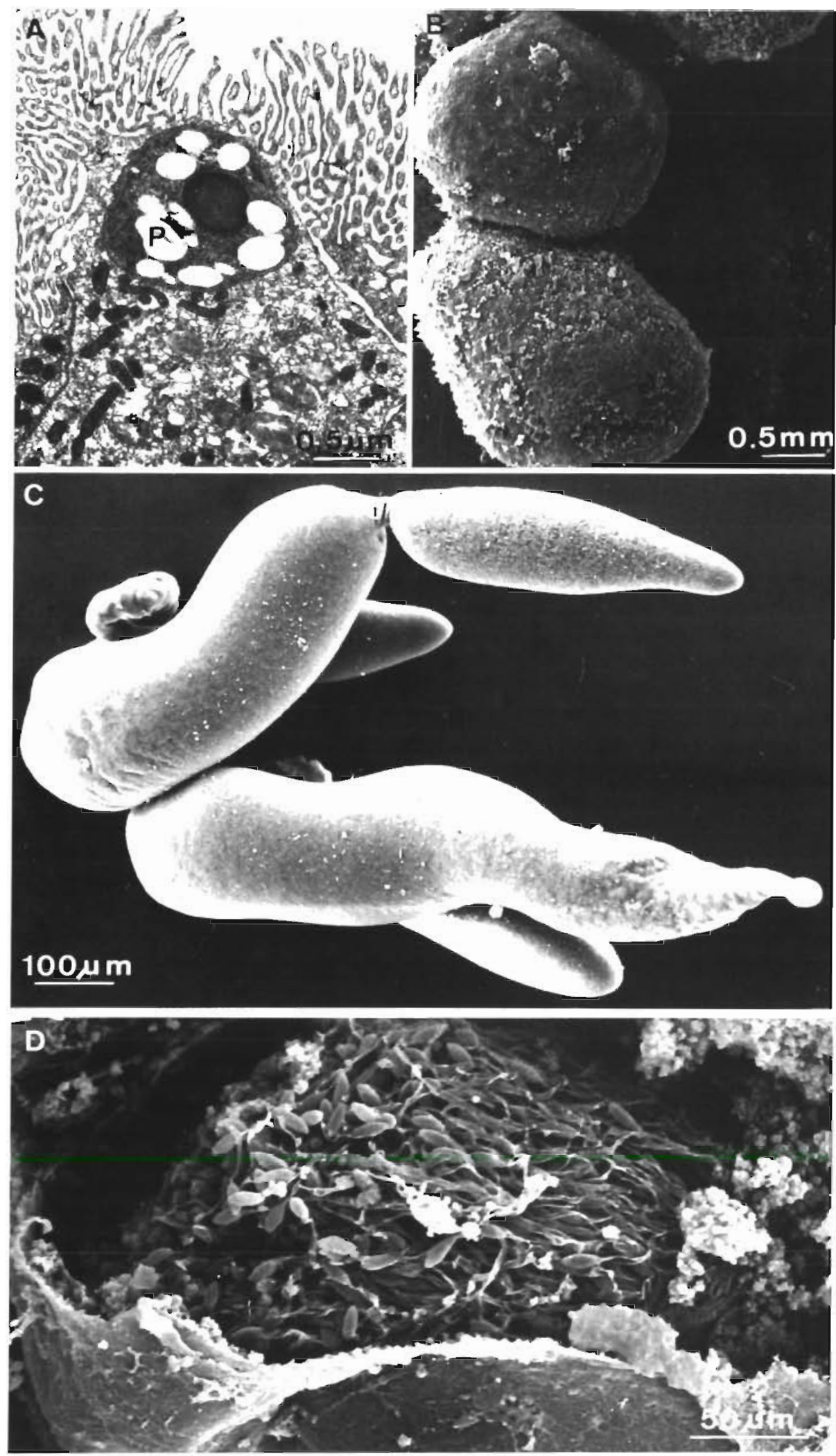

Fig. 5. Life-stages of Lithocystis sp., a gregarine parasite of the spatangoid echinoid Echinocardium cordatum. (A) Sporozoite within digestive cell of gastric caecum. P: paraglycogen granule. (B) Intracoelomic brown body containing gregarinean cysts. (C) Intracoelomic gamonts in syzygyan process. (D) Gametocyst with mature spores (B \& C after De Ridder \& Jangoux 1984; A \& D courtesy of C. De Ridder) 
Ridder \& Jangoux 1984) as is also the case with gregarines from holothuroids. However, a peculiar and conspicuous host reaction occurs with spatangoid gregarines (Léger 1897, Pixell-Goodrich 1915, Fauré-Fremiet 1926, Brownell \& McCauley 1971, De Ridder \& Jangoux 1984, Coulon \& Jangoux 1987). Some trophozoites are massively attacked by the host's coelomocytes which surround them. Coelomocytes progressively change their shape thus attaining a sharp-pointed appearance. The coelomocytes are so numerous and their reaction so intense that the parasite rapidly takes on the appearance of a minute pincushion. Such coelomocyte behavior has been interpreted either as a normal defense reaction against encysting trophozoites (Léger 1897) or as a reaction only against necrotic trophozoites (Pixell-Goodrich 1915, Brownell \& McCauley 1971). De Ridder \& Jangoux (1984) reported that coelomocyte reaction could as easily affect single trophozoites as paired gamonts, depending presumably on gregarine motility; they suggested such reaction might be a way of preventing the formation of cysts. Investigations by Coulon \& Jangoux (1987) indicated that coelomocyte reaction always lead to the death of the gregarines, covered individuals being either dying or necrotic. They showed moreover that paired gamonts are more sensitive to coelomocytes than single trophozoites.

Both Pixell-Goodrich (1915) and Coulon \& Jangoux (1987) reported that several gregarine species may coinfest spatangoid echinoids. The latter authors recognized up to 5 species in individuals of a North Sea population of Echinocardium cordatum, viz. 3 intracoelomic species and 2 intrahemal species. Infestation takes place through the digestive cells of the gastric caecum where early growth of trophozoites occur. Trophozoites reach then either the ambulacral hemal lacunae or the body cavity depending on the species. Differential sensitivity to coelomocytes appears to occur according to the species of intracoelomic gregarine (Coulon \& Jangoux 1987).

According to Brownell \& McCauley (1971), the gonads of some gregarine-infested Brisaster latifrons contain 'encysted sporozoites' of Lithocystis sp. The authors strongly doubted that such sporozoite encystment is part of the normal life cycle of the parasite as these sporozoites generally appear necrotic or partly decomposed. They noted, however, that the infestation of the gonad may be so high that its normal structure is changed and that it is filled with phagocytes and cell debris rather than germ cells.

A few gregarines parasitize suspension-feeding holothuroids of the genus Cucumaria (Woodcock 1906 , Djakonov 1923, Pixell-Goodrich 1929). Infestation was supposed to take place through the respiratory current; cysts or spores lying on the sediment would be sucked up with the water current through the cloaca and thus into the respiratory trees. Of the 2 gregarine species studied by Woodcock (1906) and Pixell-Goodrich (1929) Lythocystis cucumariae passes through its whole life cycle in the wall of the respiratory trees, while Lithocystis minchini is enclosed throughout most of its life cycle in cup-like outgrowths formed by the host's mesothelium and connective tissue on the inner side of the holothuroid's body wall. Diplodina gonadipertha - the gregarine agent of Cucumaria frondosa investigated by Djakonov (1923) - occurs only in the host's gonad. While Djakonov did not observe early infestation stages, he described almost the whole gregarine life cycle, from growing trophozoite to dehiscent cyst. Small trophozoites mostly attach to the coelomic wall of the gonad, while enlarged (growing) trophozoites are located within the gonad's hemal lacunae. Cysts at different stages of sporulation lie exclusively inside the gonadal lumen. When mature, sporozoites are said to be liberated into the gonad and discharged outside through the gonoduct. Host reaction takes place either within the hemal lacunae or within the gonadal lumen, since Djakonov (1923) reported the occurrence of invading coelomocytes that sometimes destroy the gregarines. He also reported that the parasite partially destroyed the gonad, the degree of destruction depending on the intensity of infestation.

The single species of Coccidia which parasitizes echinoderms, Ixoreis psychropotae, is known from the deep-sea holothuroid Psychropotes longicauda (see Massin et al. 1978). Like most of the other holothuroid sporozoans, I. psychropotae was found in the gutassociated hemal system where it may occur in very high numbers (Fig. 6).

Apicomplexa presumably are present in most deposit-feeding echinoderms although only rather few species have been recorded. Even with the most common species, information on their life cycle, biology and host effects is very limited. For instance, how do most echinoderms expel sporozoan cysts? Authors agree that ripe cysts of spatangoid gregarines are simply embedded into coelomic brown bodies which are liberated only at the echinoid's death. This implies that ripe cysts may have to wait up to 10 yr before being able to start a new cycle (Coulon \& Jangoux 1987). Presumably holothuroid gregarines are eliminated more rapidly as their hosts easily - sometimes seasonally - eviscerate. A variation in infestation levels, correlated with the seasonal evisceration of Stichopus tremulus, was reported by Jespersen \& Lützen (1971) for an undescribed species of sporozoan inhabiting the hemal lacunae of the stomach. Undoubtedly, sporozoans induce an echinoderm immune response, for instance the coelomocyte reaction of spatangoids 


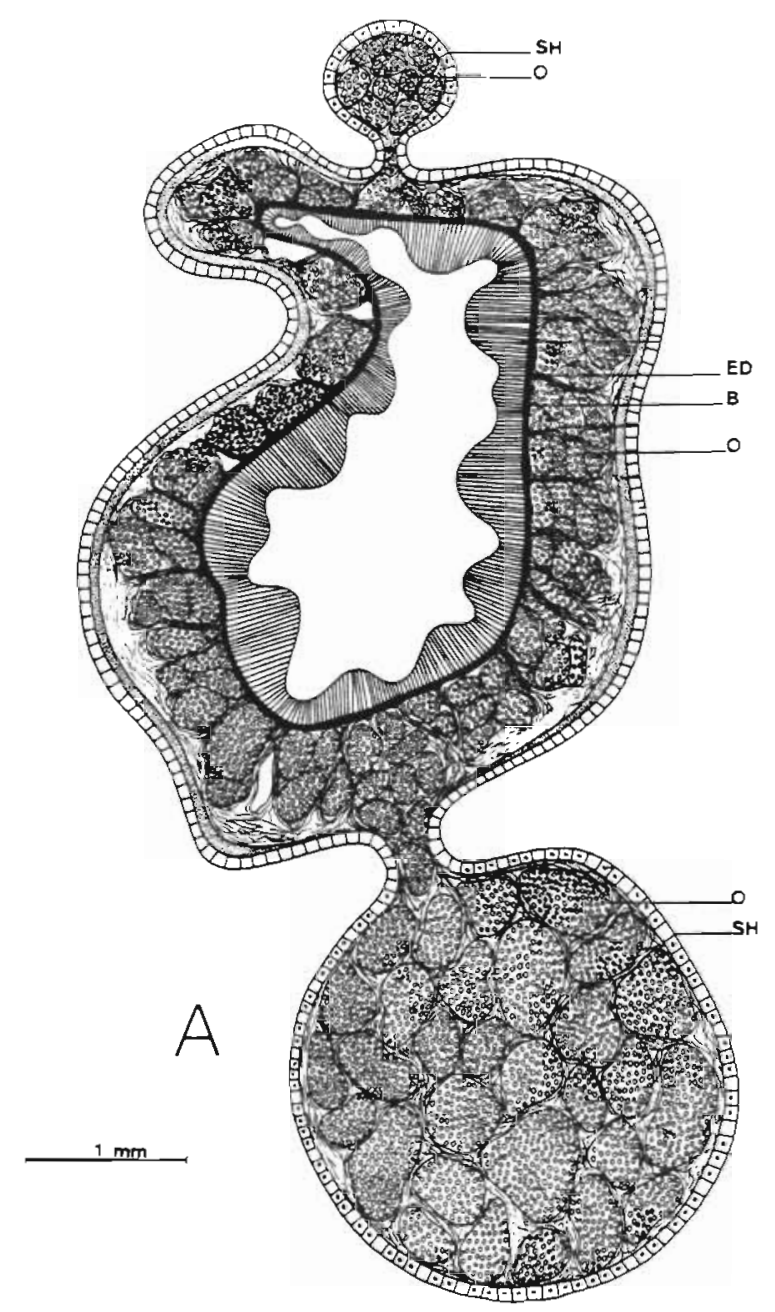

against free stages of gregarines. Intracoelomic gametocysts are presumed to be inocuous while intracoelomic free stages are harmful, i.e. they do compete for energy supply (Coulon \& Jangoux 1987). The detrimental effect of gregarines will be thus directly linked to the number of free stages housed by the spatangoids, occurrence of cysts meaning only that individuals have suffered from gregarinose in the past.

Whether or not a host's reaction occurs against intrahemal free stages of gregarines is not documented. However, tissue (connective tissue) reactions were seen around intrahemal cysts (Pixell-Goodrich 1929. Changeux 1961). When mass-infestations occur (such as those described in holothuroids by PixellGoodrich 1925 and Massin et al. 1978) the hemal lacunae are everywhere distended by cysts and the hemal fluid can no longer circulate. One could consider that the formation of 'stalked gregarines', as seen in some holothuroids parasitized by Cystobia spp. (see Changeux 1961), is actually a host reaction which removes parasites from the circulating hemal fluid.

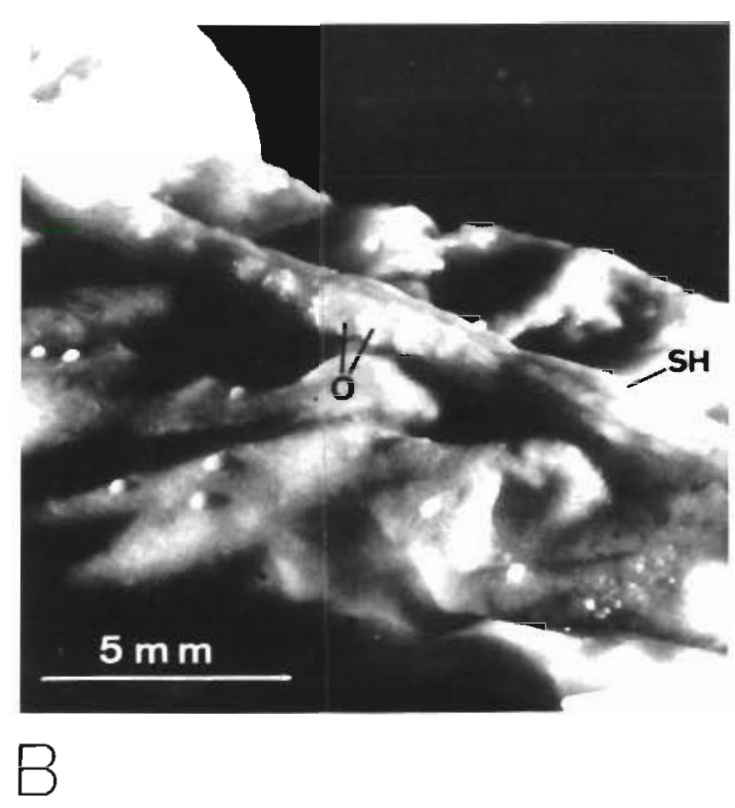

Fig. 6. Ixoreis psychropotae, a coccidian parasite of the deepsea holothuroid Psychropotes longicauda. (A) Diagramatic cross-section through intestine showing coccidian cysts in hemal lacunae and hemal vessels of the gut. (B) Outer view of gut wall of an infested individual. B: basal lamina, ED: digestive epithelium; $\mathrm{O}$ : coccidian cysts; $\mathrm{SH}$ : hemal vessels. (After Massin et al. 1978)

\section{Agents: Sporozoa (Acetospora)}

A single species of Acetospora, the haplosporidian Haplosporidium comatulae, is known to parasitize echinoderms (LaHaye et al. 1984). It was found in the gut hemal lacunae of the tropical Pacific comatulid Oligometra serripinna. Infested individuals harbored several life-history stages of the haplosporidian. The parasites have an obvious detrimental effect on their host in causing a marked reduction of the thickness of the gut wall.

\section{Agents: Ciliata}

Ciliates associated with echinoderms have been reported by many authors. They live within the digestive system of some echinoderms - regular echinoids crinoids, and synaptid holothuroids - as well as in the respiratory trees of a few holothuroids (for a detailed bibliography see Barel \& Kramers 1977). According to Powers (1935) and subsequent authors, these ciliates 
are clearly non-pathogenic and must be considered entocommensal protozoans strictly depending on the echinoderm digestive biotope for survival.

The only ciliate which definitely acts as echinoderm parasite is the astomatous(?) holotrich Orchitophyra stellarum, originally described by Cépède (1907a, b) who found it in the testes of the asteroid Asterias rubens (Fig. 7). Since then, $O$. stellarum has been reported several times from asteroid gonads (Table 3). The ciliate parasitizes mostly male gonads in which it causes a progressive breakdown of germinal tissue. Most of the infested male asteroids were completely castrated (Vevers 1951). Female gonads may also be affected but they are seemingly not destroyed as their eggs are said to be fertilizable (Smith 1936). However, Burrows (1936) noted that spawned eggs often have ciliates within their membrane: the ciliates move around the yolk and consume it, being apparently unable to leave the egg membrane. In view of the economical interest in controlling populations of oyster-or mussel-eating asteroids, attemps were made to perform experimental infestations but these were all unsuccessful (Cépède 1910, Piatt 1935, Burrows 1936). A peculiar indirect effect of the infestation by $O$. stellarum was reported by Childs (1970) and Bang
(1982), namely, clumping of coelomacytes on glass did not occur in individuals of Asterias forbesi in which the ciliate was present in the gonads. According to Taylor \& Bang (1978) and Bang (1982), recovery from infestation and return to normal glass-clumping of coelomocytes generally occur within 10 to $15 \mathrm{~d}$ under laboratory conditions.

Other ciliates claimed as echinoderm parasites have been noted. Ball (1924) briefly described new species of ciliates, supposedly parasites of gut and gonads of regular echinoids (Diadema sp., Echinometra sp., Toxopneustes sp.), and André (1910) and Cuénot (1912) noted the occurrence of the hymenostomatous holothrich Cryptochilum echini in gut, coelomic cavity and gonads of the echinoids Paracentrotus lividus and Psammechinus miliaris. No attempt was made to definitely prove the parasitic nature of these ciliates. Intracoelomic ciliates also occur in the coelomic cavity of Lytechinus variegatus which similarly harbors in its coelom individuals of the turbellarian Syndysirynx franciscanus. According to Jennings \& Mettrick (1968) ciliates form the bulk of the diet of the turbellarians.

Experimental infestations of the coelomic cavity of Asterias rubens by the ciliate Anophrys sp. were performed by Bang $(1975,1982)$. When the asteroids were

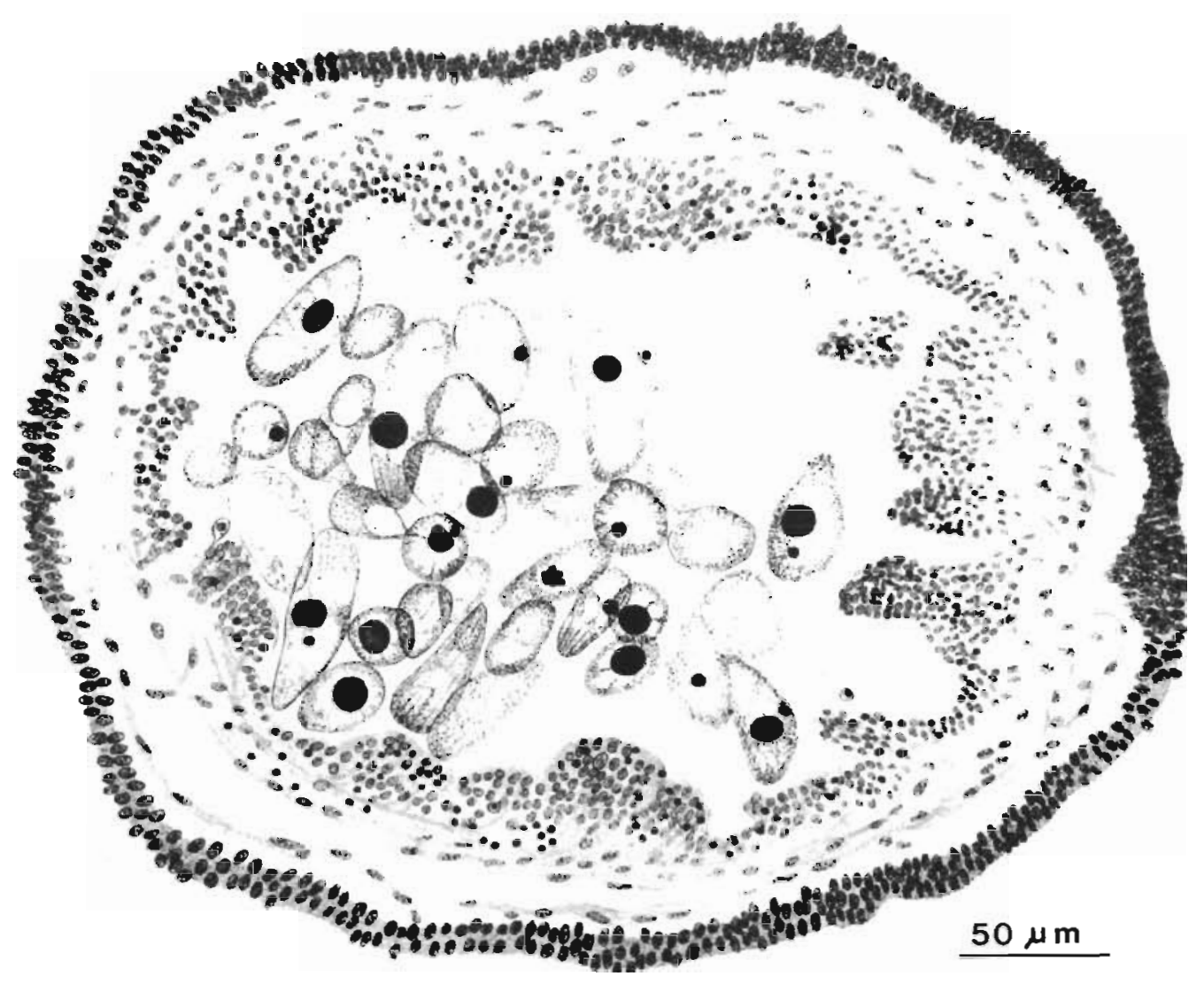

Fig. 7. Asterias rubens. Cross-section of testes showing infestation by the ciliate protozoan Orchitophyra stellarum. (After Cépède 1910) 
Table 3. Infestation of asteroid gonads by the ciliate Orchitophyra stellarum (compiled from the sources indicated)

\begin{tabular}{|c|c|c|c|}
\hline Host & Incidence of parasitism & Geographical area & Sources \\
\hline \multirow[t]{3}{*}{ Asterias forbesi } & $\begin{array}{l}9 \% \text { of male asteroids infested (no data } \\
\text { on female asteroids) }\end{array}$ & $\begin{array}{l}\text { N.W. Atlantic (Long Island } \\
\text { Sound) }\end{array}$ & Piatt (1935) \\
\hline & $\begin{array}{l}\text { Male asteroids ( } 43 \text { infested } / 326 \text { investi- } \\
\text { gated); female asteroids ( } 4 \text { infested } / 382 \\
\text { investigated) }\end{array}$ & $\begin{array}{l}\text { N.W. Atlantic (Milford, } \\
\text { Connecticut) }\end{array}$ & Burrows (1936) \\
\hline & $\begin{array}{l}\text { Infestations of male asteroids varied } \\
\text { from } 1 \text { to } 20 \% \text { depending on locality }\end{array}$ & $\begin{array}{l}\text { N.W. Atlantic (Long Island } \\
\text { Sound) }\end{array}$ & Galtsoff \& Loosanoff (1939) \\
\hline \multirow[t]{3}{*}{ Asterias rubens } & $\begin{array}{l}\text { Male asteroids ( } 3 \text { infested/ } 3000 \text { investi- } \\
\text { gated); no female asteroid infested }\end{array}$ & $\begin{array}{l}\text { English Channel (Boulogne, } \\
\text { Wimereux) }\end{array}$ & Cépède $(1907 a, b, 1910)$ \\
\hline & $\begin{array}{l}1 \text { to } 28 \% \text { of the asteroid population in- } \\
\text { fested according to season; no female } \\
\text { asteroid infested }\end{array}$ & English Channel (Plymouth) & Vevers (1951) \\
\hline & Ca $1 \%$ of male asteroids infested & North Sea (Belgium) & Jangoux \& Vloebergh (1973) \\
\hline \multirow[t]{2}{*}{ Asterias vulgaris } & $25 \%$ female asteroids infested & $\begin{array}{l}\text { N.W. Atlantic (Prince } \\
\text { Edward Island) }\end{array}$ & Smith (1936) \\
\hline & $\begin{array}{l}33 \% \text { of male asteroids infested; no } \\
\text { female asteroids infested }\end{array}$ & $\begin{array}{l}\text { N.W. Atlantic (Guif of } \\
\text { Maine) }\end{array}$ & Lowe (1978) \\
\hline Sclerasterias richardi & $\begin{array}{l}0 \text { to } 25 \% \text { of the asteroids collected in- } \\
\text { fested according to season }\end{array}$ & $\begin{array}{l}\text { Mediterranean Sea (off } \\
\text { Calvi, Corsica) }\end{array}$ & Febvre et al. (1981) \\
\hline
\end{tabular}

injected with the blood of crabs (genera Carcinus or Cancer) infested by Anophrys sp., the parasites were effectively cleared from the coelom within $6 \mathrm{~h}$. After subsequent injections, the parasites were both cleared and lysed in less than $1 \mathrm{~h}$.

\section{DISEASES CAUSED BY PROTOPHYTANS (ALGAE)}

Mortensen (1897) and Mortensen \& Rosevinge (1910) described a unicellular green alga, Coccomyxa ophiura, that parasitizes 2 species of ophiuroids from the Danish seas, Ophiura texturata and Ophiura albida, and can also infest Ophiura sarsi (see Mortensen 1933). The first signs appear on the aboral surface of disc and arms where the algae form small green subepidermal patches. The algae are generally located within the organic meshes of the calcareous plates of ophiuroids. According to the above-mentioned authors the algae progressively dissolve the skeletal plates forming irregular holes in which dense masses of algal cells occur. The algal masses grow, building conspicuous subepidermal green cushions which progressively unite. Soon afterwards, the epidermis disintegrates inducing loss of arms and/or coelomic perforations of the disc, followed by death. Similar diseases caused by the closely related algae Coccomyxa astericola occur in the asteroids Hippasteria phrygiana and Solaster endeca (see Mortensen \& Rosevinge 1933).

According to Johnson \& Chapman (1970b) the regenerating spines of an abnormally pale Strongylocentrotus franciscanus carried heavy internal infections by the diatom Navicula aff. endophytica. They suggested that this unusual infection could be linked to a shortage of red spherule cells. These cells are indeed thought to act as 'general disinfectant' in wounded and regenerating areas preventing tissue colonization by foreign cells (see also Johnson \& Chapman 1970a, Karp \& Coffaro 1982, Maes et al. 1986). The single observation by Lawrence \& Dawes (1969) of Fosliella farinosa (red coralline alga) growing over the spine epiderm of the echinoid Heterocentrotus trigonarius might also be related to a shortage in red spherule cells. A similar assumption might be made regarding the observation (Mortensen 1943) of a brownish mass of incrusting algae (Melobesia sp.) partly covering the body surface of the echinoid Temnopleurus hardwicki.

Mass mortalities of the spatangoid echinoid Echinocardium cordatum, related to a dinoflagellate bloom, occurred along the east coast of Ireland (Helm et al. 1974). There is no evidence that mortality was induced by dinoflagellate toxins. According to Helm et al., it resulted from decomposition of the bloom in conjunction with calm, sunny weather. These circumstances may have caused oxygen depletion in the substrate occupied by $E$. cordatum. Individuals which did not die in their burrow emerged and succumbed to 
exposure or predation. A similar bloom-related mass mortality was reported by Cross \& Southgate (1980) for the echinoid Paracentrotus lividus.

\section{DISEASES CAUSED BY UNIDENTIFIED AGENTS}

Mass mortalities of littoral asteroids and echinoids have been reported repeatedly since the early eighties. One can reasonably assume they were caused by as yet unidentified bacteria or protistans

Mass mortalities of the asteroid Heliaster kubinji, a top carnivore in the rocky intertidal zone of the Gulf of California, were recorded by Dungan et al. (1982). Individuals initially exhibit whitish lesions on their aboral surface. The lesions rapidly enlarge until the entire animal fragments. High concentrations of bacteria are found in the lesions but it is not known whether bacterial infection is the primary cause of death. The authors hypothesize that prolonged elevated temperature, perhaps in conjunction with other factors, renders the asteroid increasingly susceptible to infection by an as yet unidentified pathogen. Mortality of $H$. kubinji approached $100 \%$ and within 2 wk the asteroids had virtually disappeared from the study site.

Mass mortalities of the echinoid Strongylocentrotus droebachiensis, attributed to disease, occurred along the Atlantic coast of Canada (Nova Scotia) (Miller \& Colodey 1983, Moore \& Miller 1983, Scheibling 1984, Scheibling \& Stephenson 1984). The disease symptoms are not focal and involve a general infiltration of tissues with coelomocytes (Jones et al. 1985a). Symptoms occur primarily in the body wall (loss of muscle function in tube feet, spines, and mouth) and in the coelomic fluid (reduction in number of spherule cells; incomplete clotting of phagocytes). Amoebae were identified in tissues of diseased individuals (Jones et al. 1985b; see also Li et al. 1982). They ingest cell debris in degenerating tissues, but it is not known whether they are pathogenic or are secondary invaders in diseased echinoids (no specific response by coelomocytes to amoebae has been observed). Scheibling \& Stephenson (1984) demonstrate that the extent of mortality in $S$. droebachiensis populations is correlated with temperature (intensity and duration above a lower limit). According to Miller (1985a) echinoids appear to lack natural resistance to disease, at least at high temperature $\left(>12{ }^{\circ} \mathrm{C}\right)$. The causative disease agent is virulent, apparently species-specific, can be maintained and transferred in the laboratory, and is waterborne (Miller 1985b). Consequently, Miller considers the potential impact of controlling echinoids via the pathogen to be considerable, especially in subtidal areas where $S$. droebachiensis dominates.

$A$ widespread and conspicuous mass mortality of the echinoid Diadema antillarum occurred in the Caribbean (Lessios et al. 1983, 1984a, 1984b, Bak et al. 1984 Murillo \& Cortés 1984, Hughes et al. 1985, Hunte et al. 1986). Population densities of $D$. antillarum were reduced to 1 to $6 \%$ of their previous levels in Panama (Lessios et al. 1983), to $0.6 \%$ in Curaçao (Bak et al. 1984 ), to $1 \%$ in Jamaica (Hughes et al. 1985), and to $7 \%$ in Barbados (Hunte et al. 1986). Other species of echinoid remained unaffected, indicating a high level of agent specificity. Bak et al. (1984) and Hughes et al. (1985) briefly described the symptomatology of the disease: (1) accumulation of colorless mucus on many spines, especially at their tip, (2) development of dermal lesions at spots over the test and the peristome, (3) break and/or loss of spines, (4) progressive exposure of the whole skeleton and decomposition of the remaining tissue. The death of affected individuals occurred after $4 \mathrm{~d}$ or so from the first visible change. According to Hunte et al. (1986), echinoids with test diameter between 20 and $40 \mathrm{~mm}$ were more severely affected than smaller or larger individuals. Except the disease virulence, there are striking similarities between the described symptoms and those of baldsea-urchin disease. Most authors agree in considering the causative agent to be a water-born pathogen transported by oceanic currents. Lessios et al. (1984a) pointed out that the effects of the causative mortality agent extended over a geographic area of ca 3.5 million $\mathrm{km}^{2}$, causing the most widespread epidemic ever documented for marine invertebrates.

Acknowledgements. I thank Professors O. Kinne and J.M. Lawrence for criticism; Dr C. Massin, for helping with literature research; N. Biot and Dr G. Coppois, for assisting in the preparation of the manuscript.

\section{LITERATURE CITED}

André, E. (1910). Sur quelques infusoires marins parasites et commensaux. Revue suisse Zool. 18: 173-187

Arvy, L. (1957). Contribution à la connaissance des 'corps bruns' des Holothuridae. C. I hebd. Séanc. Acad. Sci., Paris 245: 2543-2545

Azzolina, J. F. (1983). Evolution de la maladie de l'oursin comestible Paracentrotus lividus (Lmk.) dans la Baie de Port-Cros (Var, France). Rapp. P.-v. Réun. Commn. int. Explor. Scient. Mer Méditer 28: 263-264

Baer, J. G. (1951) Ecology of animal parasites. Univ. Illinois Press, Urbana, Illinois

Ball, R. J. (1924). Some new parasites of the Bermuda Echinoidea. Anat. Rec. 29: 125

Bak, R. P. M., Carpay, M. J. E., Ruyter van Steveninck, E. D. de (1984). Densities of the sea urchin Diadema antillarum before and after mass mortalities on the coral reefs of Curaçao. Mar Ecol. Prog. Ser 17: 105-108

Bang, F. B. (1975). A search in Asterias and Ascidia for the beginnings of vertebrate immune responses. Ann. N. Y. Acad. Sci. 266: 334-342

Bang, F. B. (1982). Disease processes in seastar: a Metchniko- 
vian challenge. Biol Bull. mar biol. Lab., Woods Hole 162: 135-148

Bang, F. B., Lemma, A. (1962). Bacterial infection and reaction to injury in some echinoderms. J. Insect Pathol. 4: 401-414

Barel, C. D., Kramers, P. G. (1970). Notes on associates of echinoderms from Plymouth and the coast of Brittany. Proc. K. ned. Akad. Wet. (C) 73: 159-170

Barel, C. D., Kramers, P. G. (1977). A survey of the echinoderm associates of the north-east Atlantic area Zool. Verh., Leiden 156: 1-159

Bogolopeva, I. I. (1953). Gregarines of Peter the Great Bay Trav. Inst. Acad, Sci. USSR 13. (Russian)

Boolootian, R. A., Giese, A. C., Tucker, J. S., Farmanfarmaian, A. (1959). A contribution to the biology of a deep sea echinoid, Allocentrotus fraguils (Jackson). Biol. Bull. mar. biol. Lab., Woods Hole 116: 362-372

Boudouresque, C. F., Nedelec, H., Shepherd, S. A. (1980). The decline of a population of the sea urchin Paracentrotus lividus in the Bay of Port-Cros (Var, France). Trav. scient. Parc nat. Port-Cros 6: 243-251

Boudouresque, C. F., Nedelec, H., Shepherd, S. A. (1981). The decline of a population of the sea urchin Paracentrotus lividus in the Bay of Port-Cros (Var, France). Rapp. P.-v. Réun. Commn. int. Explor. Scient. Mer Méditerr. 27; 223-224

Briot, A. (1906). Sur les corps bruns des holothuries. C.r. Séanc. Soc. Biol. 60: 1156-1157

Brownell, C. L., McCauley, J. E. (1971). Two new parasites (Protozoa: Telosporea) from the spatangoid-urchin Brisaster latifrons. Zool. Anz. 186: 141-147

Burrows, R. B. (1936). Further observations on parasitism in the starfish. Science $84: 329$

Cépède, C. (1907a). La castration parasitaire des étoiles de mer mâles par un nouvel infusoire astome: Orchitophyra stellarum n.g., n.sp. C.r. hebd. Séanc. Acad. Sci., Paris 145: 1305-1306

Cépède, C. (1907b). Sur un nouvel infusoire astome, parasite des testicules des étoiles de mer. Considérations générales sur les Astomata. C.r. Ass. Franç. Avanc. Sci. 36: 258

Cépède, C. (1910). Recherches sur les infusoires astomes. Archs Zool. exp. gén. 3: 341-609

Changeux, J. P. (1961). Contribution à l'étude des animaux associés aux holothurides. Vie Milieu 10 (Suppl.): 1-124

Chesher, R. H. (1968). The systematics of sympatric species in West Indian spatangoids: a revision of the genera Brissopsis, Plethotaenia, Paleopneustes, and Saviniaster. Stud. Trop. Oceanogr. 7: 1-168

Chesher, R. H. (1969). Contributions to the biology of Meoma ventricosa (Echinoidea: Spatangoida). Bull. mar Sci. 19: $72-110$

Childs, J. N. (1970). Failure of coelomocytes of some Asterias forbesi to clump on glass. Biol. Bull. mar. biol. Lab., Woods Hole 139: 418

Coffaro, K. (1978). Clearance of bacteriophage T4 in the sea urchin Lytechinus pictus. J, invert. Pathol. 32: 384-385

Coulon, P., Jangoux, M. (1987). The gregarine species (Apicomplexa) parasitic in the burrowing echinoid Echinocardium cordatum: occurrence and host reaction. Dis. aquat. Org. 2: 135-145

Cross, T. E., Southgate, T. (1980). Mortalities of fauna of rocky substrates in south-west Ireland associated with the occurrence of Gyrodinium aureolum blooms during autumn 1979. J. mar. biol. Ass. U. K. 60: 1071-1073

Cuénot, L. (1891). Protozoaires commensaux et parasites des échinodermes. Rev. biol. Nord France 3: 285-300

Cuénot, L. (1892). Commensaux et parasites des échinodermes (deuxième note). Rev. biol. Nord France 5: 1-22
Cuénot, L. (1912). Contribution à la faune du Bassin d'Arcachon. V. Echinodermes. Bull. Stn biol. Arcachon 14: $17-116$

Delavault, R., Leclerc, M. (1969). Bactéries pathogènes découvertes chez Asterina gibbosa Penn. (Echinoderme, Astéride). C.r. hebd. Séanc. Acad. Sci., Paris 268: $2380-2381$

De Ridder, C., Jangoux, M. (1984). Intracoelomic parasitic Sporozoa in the burrowing spatangoid, Echinocardium cordatum (Pennant) (Echinodermata, Echinoidea): coelomocyte reaction and formation of brown bodies. Helgoländer Meeresunters. 37: 225-231

De Ridder, C., Jangoux, M., De Vos, L. (1985). Description and significance of a peculiar intradigestive symbiosis between bacteria and a deposit-feeding echinoid. J. exp. mar. Biol. Ecol. 91: 65-76

Djakonov, M. D. (1923). Diplodina gonadipertha, n. sp. a new neogamous gregarine, parasite of the gonads of Cucumaria frondosa (Gunn.). Russk. Arch. Protist. 2: 127-147. (Russian; French summary)

Dogiel, V. (1906). Beiträge zur Kenntnis der Gregarinen. I. Cystobia chirodotae nov. sp. Arch. Protistenk. 7: 106-130

Dungan, M. L., Miller, T. E., Thomson, D. A. (1982). Catastropic decline of a top carnivore in the Gulf of California rocky intertidal zone. Science 216: 989-991

Fauré-Fremiet, E. (1926). Différents états morphologiques des amibocytes d'Echinocardium cordatum. C.r. Séanc. Soc. Biol. 95: 548-550

Febvre, M., Fredj-Reygrobellet, D., Fredj, G. (1981). Reproduction sexuée d'une astérie fissipare, Sclerasterias richardi (Perrier, 1882). Int. J. invert. Repr. 3: 193-208

Galtsoff, P. S., Loosanoff, V. L. (1939). Natural history and method of controlling the starfish (Asterias forbesi, Desor). Bull. Bur. Fish., Wash. 31: 75-132

Giard, A. (1876). Sur une nouvelle espèce de sporospermie (Lithocystis schneideri), parasite de l'Echinocardium cordatum. C.r. hebd. Séanc. Acad. Sci., Paris 82: 1208-1210

Giese, A. C. (1961). Further studies on Allocentrotus fragilis, a deep-sea echinoid. Biol. Bull. mar. biol. Lab., Woods Hole 121: 141-150

Gilles, K. W., Pearse, J. S. (1986). Disease in sea urchins Strongylocentrotus purpuratus: experimental infection and bacterial virulence. Dis. aquat. Org. 1: 105-114

Guerinot, M. L., Patriquin, D. G. (1981). The association of $\mathrm{N}_{2}$ fixing bacteria with sea-urchins. Mar. Biol. 62: 197-207

Helm, M. M., Hepper, B. T., Spencer, B. E., Walne, P. R (1974). Lugworm mortalities and a bloom of Gyrodinium aureolum Hulburt in the eastern Irish Sea, autumn 1971. J. mar. biol. Ass. U. K. 54: 857-869

Hérouard, D. (1902). Holothuries provenant des campagnes de la Princesse Alice (1892-1897). Rés. Camp. scient. Monaco 21: 1-61

Höbaus, E., Fenaux, L., Hignette, M. (1981). Premières observations sur les lésions provoquées par une maladie affectant le test des oursins en Méditerranée occidentale. Rapp P.-v. Réun. Commn int. Explor. Scient. Mer Méditerr. 27 221-222

Holland, N. D., Nealson, K. H. (1978). The fine structure of the echinoderm cuticle and the subcuticular associated bac teria of echinoderms. Acta zool., Stockh. 59: 169-185

Hughes, T. P., Keller, B. D., Jackson, J. B. C., Boyle, M. J (1985). Mass mortality of the echinoid Diadema antillarum Philippi in Jamaica. Bull. mar Sci. 36: 377-384

Hunte, W. Côté, I., Tomascik, T (1986). On the dynamics of the mass mortality of Diadema antillarum in Barbados Coral Reefs 4: 135-139 
Hyman, L. H. (1955). The invertebrates. IV. Echinodermata. McGraw Hill, New York

Jangoux, M. (1984). Diseases of echinoderms. Helgoländer Meeresunters, 37: 207-216

Jangoux, M., Voebergh, M. (1973). Contribution à l'étude du cycle annuel de reproduction d'une population d'Asterias rubens L. (Echinodermata, Asteroidea) du littoral belge. Neth. J. Sea Res. 6: 389-408

Janssens, F. A. (1903). Production artificielle de larves géantes chez un échinide. C.r. hebd. Séanc. Acad. Sci., Paris 137: $274-276$

Jennings, J. B., Mettrick, D. F. (1968). Observations on the ecology, morphology and nutrition of the rhabdocoel turbellarian Syndesmis franciscana (Lehman, 1946) in Jamaica. Caribb. J. Sci. 8: 57-69

Jespersen, A., Lützen, J. (1971). On the ecology of the aspidochirote sea cucumber Stichopus tremulus (Gunnerus). Norw. J. Zool. 19: 117-132

Johnson, P. T. (1969). The coelomic elements of sea urchin (Strongylocentrotus). III. In vitro reactions to bacteria. J. invert. Pathol. 13: 42-62

Johnson, P. T. (1971). Studies on diseased urchins from Point Loma. Ann. Rep. Kelp Habit. Impr. Project (1970-1971). Calif. Inst. Technol., Pasadena, p. 82-90

Johnson, P. T., Chapman, F. A. (1970a). Abnormal epithelial growth in sea urchin spines (Strongylocentrotus franciscanus). J. invert. Pathol. 16: 116-120

Johnson, P. T., Chapman, F. A. (1970b). Infection with diatoms and other microorganisms in sea urchin spines (Strongylocentrotus franciscanus). J. invert. Pathol. 16: 268-276

Johnson, P. T., Chapman, F. A. (1971). Comparative studies on the in vitro response of bacteria to invertebrate body fluids. III. Stichopus tremulus (sea cucumber) and Dendraster excentricus (sand dollar). J. invert. Pathol. 17: 94-106

Johnson, P. T., Chien, P. K., Chapman, F. A. (1970). The coelomic elements of sea urchins (Strongylocentrotus). V. Ultrastructure of leukocytes exposed to bacteria. J. invert. Pathol. 16: 466-469

Jones, G. M., Hebda, A. J., Scheibling, R. E., Miller, R. J. (1985a). Histopathology of the disease causing mass mortality of sea urchins (Strongylocentrotus droebachiensis) in Nova Scotia. J. invert. Pathol. 45: 260-271

Jones, G. M., Hebda, A. J., Scheibling, R. E., Miller, R. J. (1985b). Amoebae in tissues of diseased echinoids (Strongylocentrotus droebachiensis) in Nova Scotia. In: Keegan, B. F., O'Connor, B. D. (ed.) Proc. intern. Echinoderm Conf., Galway. Balkema, Rotterdam, p. 289-293

Kaneshiro, E. S., Karp, R. D. (1980). The ultrastructure of coelomocytes of the sea star Dermasterias imbricata. Biol. Bull. mar biol. Lab., Woods Hole 159: 295-310

Kinne, O. (1980). Diseases of marine animals: general aspects. In: Kinne, O. (ed.) Diseases of marine animals, Vol. I. General aspects, Protozoa to Gastropoda. Wiley, Chichester, p. 13-73

Koehler, R. (1911). Echinodermes antarctiques provenant de la Campagne du Pourquoi-Pas? C.r. hebd. Séanc. Acad. Sci., Paris 153: 735-737

Koehler, R. (1912). Les échinodermes de la mission Charcot. C.r. hebd. Séanc. Acad. Sci., Paris 155: 322-324

LaHaye, C. A., Holland, N. D., McLean, N. (1984). Electron microscopic study of Haplosporidium comatulae n. sp. (phylum Ascetospora: class Stellasporea), a holosporidian endoparasite of an Australian crinoid, Oligometra serripinna (phylum Echinodermata). Protistologica 20: $507-515$
Lawrence, J. M., Dawes, C. J. (1969). Algal growth over the epidermis of sea urchin spines. J. Phycol. 5: 269

Lecal, L. (1980). Étude des coelomocytes d'un crinoïde. Description de Cryptobia antedona, n. sp., zooflagellé bodonidé du coelome général d'Antedon bifida (Pennant). In: Jangoux, M. (ed.) Echinoderms: present and past. Balkema, Rotterdam, p. 271-275

Léger, L. (1896). L'évolution du Lithocystis schneideri, parasite de l'Echinocardium cordatum. C.r. hebd. Séanc. Acad. Sci., Paris 122: 702-705

Léger, L. (1897). Contribution à la connaissance des sporozoaires parasites des échinodermes. Étude sur le Lithocystis schneideri. Bull. scient. Fr Belg. 30: 240-264

Lessios, H. A., Glynn, P. W., Robertson, D. R. (1983). Mass mortalities of coral reef organisms. Science 222: 715

Lessios, H. A., Robertson, D. R., Cubit, J. D. (1984a). Spread of Diadema mass mortality through the Caribbean. Science 226: 335-337

Lessios, H. A., Cubit, J. D., Robertson, D. R., Shulman, M. J., Paster, M. R., Garrity, S. D., Levings, S. C. (1984b). Mass mortality of Diadema antillarum on the Caribbean coast of Panama. Coral Reefs 3: 173-182

Levine, N. D. (1977). Checklist of the species of the aseptate gregarine family Urosporidae. Int. J. Parasit. 7: 101-108

Li, M. F., Cornick, J. W., Miller, R. J. (1982). Studies of recent mortalities of the sea urchin (Strongylocentrotus droebachiensis) in Nova Scotia. Coun. Meet. int. Coun. Explor. Sea (Biol. oceanogr. Com.) C.M.-ICES/IF 46: 1-8

Lowe, G. F. (1978). Relationships between biochemical and caloric composition and reproductive cycle in Asterias vulgaris (Echinodermata: Asteroidea) from the Gulf of Maine. Ph. D. thesis, Univ. Maine, Orono

Ludwig, H., Hamann, O. (1889-1907). Echinodermen (Stachelhäuter). In: Bronn's Thier-Reich 2 (3): 1-1602 (5 sections)

Lützen, J. (1968). Biology and structure of Cystobia stichopi, n. sp. (Eugregarina, Family Urosporidae), a parasite of the holothurian Stichopus tremulus (Gunnerus). Nytt Mag. Zool. 16: 14-19

Maes, P., Jangoux, M. (1984). The bald-sea-urchin disease: a biopathological approach. Helgoländer Meeresunters. 37 $217-224$

Maes, P., Jangoux, M. (1985). The bald-sea-urchin disease: a bacterial infection. In: Keegan, B. F, O'Connor, B. D. (ed.) Proc. intern. Echinoderm Conf., Galway. Balkema, Rotterdam, p. 313-314

Maes, P., Jangoux, M., Fenaux, L. (1986). La maladie de l'oursin-chauve; ultrastructure des lésions et caractérisation de leur pigmentation. Annls Inst. océanogr. 62: 37-45

Märkel, K. (1981). Experimental morphology of coronar growth in regular echinoids. Zoomorphology 97: 31-52

Massin, C. (1984). Structures digestives d'holothuries Elasipoda (Echinodermata): Benthogone rosea Koehler, 1896 et Oneirophanta mutabilis Théel, 1879. Archs Biol., Bruxelles 95: 153-185

Massin, C., Jangoux, M., Sibuet, M. (1978), Description d'IXoreis psychropotae, nov. gen., nov. sp., coccidie parasite du tube digestif de l'holothurie abyssale Psychropotes longicauda Théel. Protistologica 14: 253-259

Messer, L. I., Wardlaw, A.. C. (1980). Separation of coelomocytes of Echinus esculentus by density gradient centrifugation. In: Jangoux, M. (ed.) Echinoderms: present and past. Balkema, Rotterdam, p. 319-323

Miller, R. J. (1985a). Succession in sea urchin and seaweed abundance in Nova Scotia, Canada. Mar. Biol. 84: $275-286$ 
Miller, R. J. (1985b). Sea urchin pathogen: a possible tool for biological control. Mar. Ecol. Prog. Ser. 21: 169-174

Miller, R. J., Colodey, A. C. (1983). Widespread mass mortalities of the green sea urchin in Nova Scotua, Canada. Mar. Biol. 73: 263-267

Minchin, E. A. (1893). Observations on the gregarines of holothurians. J. microsc. Sci. 34: 279-310

Mingazzini, P. (1891). Le gregarine delle Oloturie. Atti R. Acad. Lincei Rc. (4) 7 (1): 313-319

Moore, D. S., Miller, R. J. (1983). Recovery of marco algae following widespread sea-urchin Strongylocentrotus droebachiensis mortality with a description of the nearshore hard bottom habitat on the Atlantic coast of NovaScotia, Canada. Can. tech. Rep. Fish. Aquat. Sci. 1230: $1-94$

Mortensen, T. (1897). Smaa faunistike og biologiske Meddelelser. III. Om en Alge, der snylter hos Ophioglypha texturata og albida. Vidensk. Meddr dansk naturh. Foren. 1897: 322-324. (French summary)

Mortensen, T. (1909). Die Echinoiden. Deutsch. Südpol. Exp. 1901-1903 11 (3): 1-113

Mortensen, T. (1928). A Monograph of the Echinoidea. Part I. C. A. Reitzel, Copenhagen

Mortensen, T. (1933). Ophiuroidea. Rep. Dan. Ingolf-Exped. 4 (8): $1-121$

Mortensen, T. (1935). A Monograph of the Echinoidea. Part II. C. A. Reitzel, Copenhagen

Mortensen, T. (1936). Echinoidea and Ophiuroidea. 'Discovery' Rep. 12: 199-348

Mortensen, T. (1940). A Monograph of the Echinoidea. Part III (1) Aulodonta. C. A. Reitzel, Copenhagen

Mortensen, T. (1943). A Monograph of the Echinoidea. Part III (2) Camarodonta I. C. A. Reitzel, Copenhagen

Mortensen, I., Rosevinge, L. K. (1910). Sur quelques plantes parasites dans des échinodermes. Overs. K. danske Vidensk. Selsk. Forh. 1910 (4): 339-354

Mortensen, T., Rosevinge, L. K. (1933). Sur une nouvelle algue, Coccomyxa astericola, parasite dans une astérie. Biol. Meddr 1 (9): 1-8

Mortensen, T., Rosevinge, L. K. (1934). Sur une algue cyanophycée, Dactylococcopsis echini n. sp., parasite dans un oursin. Biol. Meddr 11 (7): 1-10

Murillo, M. M., Cortès, J. (1984). Alta mortalidad en la poblacion dej erizo de mar Diadema antillarum Philippi (Echinodermata: Echinoidea) en el Parque Nacional Cahuita, Limon, Costa Rica. Rev. Biol. trop. 32: 167-169

Nichols, D. (1979). Aboral spine loss in the European seaurchin, Echinus esculentus. In: Earll, R. C., Jones, H. D. (ed.) Observation scheme report. Underwater Conserv. Soc., London, p. 43-46

Olmsted, J. M. (1917). Comparative physiology of Synaptula hydriformis (Lesueur). J. exp. Zool. 24: 333-379

Pearse, J. S., Costa, D. P., Yellin, M. B., Agegian, C. R. (1977) Localized mass mortality of red sea urchin, Strongylocen. trotus franciscanus, near Santa Cruz, California. Fish. Bull. U. S. 53: 645-648

Pearse, J. S., Hines, A. H. (1979). Expansion of a central California kelp forest following the mass mortality of sea urchins. Mar. Biol. 51: 83-91
Piatt, J. (1935). An important parasite of starfish. Fish. Serv. Bull., U. S. Dept Commerce 247. 3-4

Pixell-Goodrich, H. L. (1915). On the life-history of the Sporozoa of spatangoids, with observations on some allied forms. J. microsc. Sci. 61: 81-104

Pixell-Goodrich, H. L. (1925). Observations on the gregarines of Chirodota. J. microsc. Sci. 69: 620-628

Pixell-Goodrich, H. L. (1929). The gregarine of Cucumaria Lithocystis minchini Woodc. and Lithocystis cucumanae n. sp. J. microsc. Sci. 73: 275-287

Powers, P. B. (1935). Studies on the ciliates of sea-urchins. Pap. Tortugas Lab. 29: 293-326

Scheibling, R. E. (1984). Echinoids, epizootics and ecological stability in the rocky subtidal off Nova Scotia, Canada. Helgoländer Meeresunters. 37: 233-242

Scheibling, R., Stephenson, R. L. (1984). Mass mortality of Strongylocentrotus droebachiensis (Echinodermata: Echinoideal off Nova Scotia, Canada. Mar. Biol. 78 153-164

Schneider, A. (1858). Uber einige Parasiten der Holothuria tubulosa. Arch. Anat. Physiol. 1858: 323-329

Service, M., Wardlaw, A. C. (1984). Echinochrome-A as a bactericidal substance in the coelomic fluid of Echinus esculentus (L.). Comp. Biochem. Physiol. 79B: 161-165

Service, M., Wardlaw, A. C. (1985). Bactericidal activity of coelomic fluid of the sea urchin, Echinus esculentus, on different marine bacteria. J. mar. biol. Ass. U. K. 65: 133-139

Smith, G. F. (1936). A gonad parasite of the starfish. Science 84: 157

Taylor, C. E., Bang, F. B. (1978). Alteration of blood clotting in Asterias forbesi associated with a ciliate infection. Biol. Bull. mar. biol. Lab., Woods Hole 155: 468

Thedorides, J., Laird, M. (1970). Quelques eugrégarines parasites d'invertébrés marins de St Andrews (Nouveau Brunswick). Can. J. Zool. 48: 1013-1016

Unkles, S. E. (1977). Bacterial flora of the sea urchin Echinus esculentus. Appl. environm. Microbiol. 34: 347-350

Vevers, H. G. (1951). The biology of Asterias rubens L. II. Parasitization of the gonads by the ciliate Orchitophyra stellarum Cépède. J. mar. biol. Ass. U. K. 29: 619-624

Wardlaw, A. C., Unkles, S. E. (1978). Bactericidal activity of coelomic fluid from the sea urchin Echinus esculentus. J. invert. Pathol. 32: 25-34

Woodcock, H. M. (1902). Investigations of the life-history of Sporozoa. Rep. Brit. Ass. Adv. Sci. 1902: 271-272

Woodcock, H. M. (1904). On Cystobia irregularis (Minch.) and allied 'neogamous' gregarines. Archs Zool. exp. gén. 2 (notes et revues) : 75-78

Woodcock, H. M. (1906). The life-cycle of Cystobia irregularis (Minch.), together with observations on other 'neogamous' gregarines. J. microsc. Sci. 50: 1-100

Yui, M. A., Bayne, C. J. (1983). Echinoderm immunology: bacterial clearance by the sea urchin Strongylocentrotus purpuratus. Biol. Bull. mar biol. Lab., Woods Hole 165 $473-486$ 